\title{
Can Technology Transfer Stimulate Labour Productivity: Experience from Nigeria Automobile Sector
}

\author{
Egwakhe, A. J. ${ }^{1}$, Amos, N. B. ${ }^{2} \&$ Nicodemus, T. ${ }^{3}$ \\ ${ }^{1}$ School of Management Sciences, Department of Business Administration and Marketing, Babcock University, \\ Ilishan- Remo, Ogun State, Nigeria \\ Correspondence: Nicodemus, T., School of Management Sciences, Department of Business Administration and \\ Marketing, Babcock University, Ilishan- Remo, Ogun State, Nigeria. E-mail: nicodemustosin@gmail.com
}

Received: February 5, 2020

Accepted: February 27, 2020

Online Published: March 3, 2020

doi:10.5539/ijbm.v15n4p1

URL: https://doi.org/10.5539/ijbm.v15n4p1

\begin{abstract}
This paper argued that technology transfer possesses operational and structural capability to stimulate labour productivity in Nigerian automobile sector. Technology transfer proxies are knowledge transfer, skill acquisition, technology infrastructure, innovation, and adoption and their fundamental effect on workforce productivity. A cross-sectional survey research design was adopted to capture the perception of respondents at a categorical point in time. There were three automobile manufacturing companies in Nigeria from which the responding organisations were drawn. The unit of analysis consisted of 675 managers and engineers who were randomly selected from a total population of 1,150. The research instrument was adapted, and its content and construct validity were established. Also, it was subjected to reliability test with Cronbach's alpha value above the minimum threshold. The hypothesis was tested using multiple regressions and the aggregate result revealed a positive significant relationship between technology transfer and labour productivity. The power of the individual result revealed that a positive significant relationship exists between the dimensions of technology transfer (skill acquisition, technology infrastructure, technology innovation, technology adoption, and labour productivity, while knowledge transfer was not significant. The study recommended sustained and progressive technology transfer to enhance workers' productivity in the sector.
\end{abstract}

Keywords: Technology transfer, labour productivity, technology infrastructure, technology innovation.

\section{Introduction}

Thriving business organisations depend on their workforce to achieve and sustain corporate performance with context observations associating labour productivity with business growth. Growth in labour productivity trajectory is presumed to produce more output in the form of goods and services for the same amount of relative work (Pfluger \& Tabuchi 2019), while deflating the cost incurred. This increase in output level of goods and services has contributed to firms' performance and engineered many nations' Gross Domestic Product growth, hence rating those nations as knowledge economy (Okonji, 2019). The field of economics and management have seen labour productivity as mathematical function expressed as output divided by input, with higher result denoting achievement of more with the same amount of resources or achieving a higher output in terms of volume and quality from the same input (Lee, Byun, \& Park, 2019). This technically measures efficiency of an organization as it converted their inputs into useful outputs (Vlajcica, Caputob, \& Dabica, 2019).

Studies (Adeyeye, 2014; Adebayo, Olagunju, Ogundipe, Salman, \& Francis, 2017) in the Nigeria context have found low level of skill acquisition, vocational training, gaps in knowledge, technical know-how, and lack of government support for talented individuals as major factors for the low level of labour productivity in manufacturing and service industry. Although the aforementioned studies did not cover the automobile manufacturing industry in Nigeria, Agwu, Dimelu, and Madukwe (2018) concluded that non adaptive innovation and not infusing technological idea/tools have brought about technical skills deficit. Similarly, Anyadike, Emeh, and Ukah (2012), Adeyeye (2014), Awotide, Diagne, and Omonona (2012) observed that the low level of labour productivity in the automobile manufacturing sector in Nigeria was due to sub-standard level of skills acquisition and absorptive capability of the workforce. Hence, Manufacturers Association of Nigeria [MAN] (2018) and National Bureau of Statistics [NBS] (2018) established that over $\$ 8$ billion is lost annually in the Nigerian automobile sector in foreign exchange through importation and also through job creation for countries of origin 
of motor vehicles imported, while about $35 \%$ of Nigerian working age are unemployed due to low level of skill acquisition, vocational training, weak knowledge and technical know-how.

In addition, similar studies (Anyadike, Emeh, \& Ukah, 2012; Awotide, Diagne, \& Omonona, 2012; Adeyeye, 2014; Colovic \& Lamotte, 2016; Anderson, 2016; Adebayo, Olagunju, Ogundipe, Salman, \& Francis, 2017; Black \& McLennan, 2016) examined the effect of technology transfer on labour productivity in the manufacturing and some focused on service industry with divergent positions and prescriptions. According to Arvanitis and Loukis (2009), labour productivity is a pivotal determinant of cost efficiency in the automobile manufacturing industry. Adeoti and Olubamiwa (2016) maintained that firms that invest more in innovative activities and encourage technology transfer achieved improvement in labour productivity. Increasing the labour productivity of an organization through technology transfer such as knowledge transfer, skill acquisition, technology infrastructure, technology adoption and technology innovation could contribute to increase in workers' output (Marx, 2017). The increase in the level of workers' productivity enables competition in the market, hence, directly improving a nation's opportunities to achieved economic growth and development (Torrent-Sellens \& Díaz-Chao, 2014).

Technology transfer has been noted in different studies as having a significant impact on labour productivity (Gallaher, Oliver, Reith, \& O'Connor, 2016). According to Nicodemus and Egwakhe (2019), technology transfer in the form of adoption, infrastructure and innovation within a business ecosystem promotes competitive advantage. This view was in agreement with Marx (2017), Torrent-Sellens and Diaz-Chao (2014) understanding that labour efficiency and competitiveness generate innovation that improves corporate performance, which results in a competitive position in the market space. Greater technology transfer results in better performance and a better competitive position of a company (Nicodemus \& Egwakhe, 2019).

Furthermore, extant literature on the impact of technology infrastructure, knowledge transfer on labour productivity (Maciulyte-Sniukiene \& Gaile-Sarkane, 2014; Rui \& Joao, 2015) found a significant positive relationship between technology infrastructure and labour productivity. Similarly, Okoli and Binuomote (2015) found a significant positive effect of information and communication technology (ICT) skill, risk management skill, and innovative skill on overall workforce productivity. This finding corroborated Newman, Rand, Talbot and Tarp (2015) findings. It is on this premise that the researchers seek to investigate how various dimensions of technology transfer (Knowledge transfer, skill acquisition, technology infrastructure, technology innovation, and technology adoption) affect labour productivity of selected automobile manufacturing companies in Nigeria.

\section{Literature Review}

\subsection{Technology Transfer and Labour Productivity}

The concept of transfer of technology has been associated with the economic and industrial development of many nations (Barnes, Black, \& Tekachanont 2017), of which developing countries could take due advantage of the growth potentials inherent in technology transfer to increase their labour productivity and efficiency levels. This idea brought about Adebayo, Olagunju, Ogundipe, and Salman (2017) defining technology transfer as the process of transferring technology from the person or organization that owns or holds it to another person or organization. Murad and Thomson (2011) defined technology transfer as an activity of dissemination of technology that occurs along various axes; among universities, from universities to businesses, from large businesses to smaller ones, from governments to businesses, across geopolitical borders, both formally and informally, and both openly and surreptitiously.

Knowledge transfer can be defined as the process by which existing knowledge, capability developed under research and development are utilized to fulfill private and public needs (Vlajcica, Caputob, \& Dabica, 2019). Argote and Ingram (2012) defined knowledge transfer as a process through which knowledge resided in a group; department or division is influenced by the experience of another unit. Rui and Joao (2015) however defined knowledge transfer as an event through which one organisation learns from the experience of another. Knowledge transfer entails the dissemination and share of not only knowledge but also strategies towards addressing a given challenge or problem (Andreea-Clara, 2015). In addition, Argote and Ingram (2000) defined knowledge transfer as a channel through which the experiences of an individual are diffused to cause a change in another, this change can also cut across groups, departments, or divisions. Nevertheless, the transmission of organisational knowledge (routine or best practices) can be physically detected through modifications in the knowledge or performance of recipient units.

Skill acquisition can be defined as the process by which individual or a group of people are trained on a particular task or function and become proficient (Santhosh, 2014). Okoli and Binuomote (2015) defined skill acquisition as a form of knowledge and technical know-how transfer and the ability to adapt new methods and 
technology in the field of manufacturing. Okoli and Binuomote (2015) further measure skill acquisition with variables such as technical skill, vocational skill, strategic skill, software application development skill, automation skill, business development skill, and intellectual skill. The argument that only an individual or groups that obtained technical manpower can operate effectively in the automobile manufacturing industry is then justifiable. Jacqueline and Joshua (2016) emphases that technical education contributes to creativity in the automobile industry in the developed countries and employees acquiring technical skills are the practical and dependable option for economic recovery and survival of any nation's economy.

Anderson (2016) defined technology infrastructure as assets such as telecommunications, word processing and management information system; automated data processing, equipment, goods, and services. Tassey (2015) viewed it as hardware and software that support information requirements, comprising computer workstations and associated software, mainframe devices, networking, and communications equipment. Babalola (2013) refers to technology infrastructure as basic installations and social facilities like roads, railway, telecommunication networks, energy supply system and water supply system of which the continuance and growth of a community depend. Babalola (2013) went further to describe it as a socio-technical system comprises of hardware, information content and computer software which support the creation, transport, storage and use of information that aids organisational performance. Technology infrastructure improves quality and reliability of products and operations.

Technology adoption was defined as a process ranging from acceptance, integration, and use of new technology in a society (Scott, Beaulieu, Rothrock, \& O'Connor, 2016). The process follows several stages, usually categorized by the groups of people who use that technology. Aromolaran, Akerele, Oyekunle, Sotola, and Taiwo (2017) defined technology adoption as the extent to which a given technology becomes accepted and incorporated into approved social practices. Organisations often seek to shape the evolution of technological applications to its own merit, especially when there is market push due to its availabilities, conveniences, need and security. According to Mathu and Tlare (2017), the concept of technology transfer is connected to technology adoption as such, the automobile manufacturing companies today requires constant innovation, new idea integration, and adoption of up-to-date production processes to achieve and sustain high productivity. Adopting technology that is changing the manufacturing industry are majorly redefining customers taste, competition and operational process across the industry (Awotide, Diagne, \& Omonona, 2012). Those essential technologies that are changing the automotive manufacturing industry include the Internet of Things (IoT), 3D printing, robots, drones, virtual reality, artificial intelligence and blockchain (PwC, 2017).

Technology innovation has been an important topic of discussion for different disciplines, such field as engineering, economics, business and science with different definitions among academics. Torrent-Sellens and Díaz-Chao (2014) defines innovation as making changes to something established by introducing something new. This definition suggests that innovation is relevant to all sphere of life and it could be radical or incremental in the form of products, processes, or services in the context of manufacturing companies. Rogers (1995) defines innovation as an idea, process, and practices that are perceived as new by an individual or group. Similarly, Akinwale (2016) defined technology innovation as system automation whereby artificial intelligent and robotic handles the production process. Technology innovation according to (Berraies \& Chaher, 2014; Carlos, 2013; Choi \& Lim, 2017) include a new designs, new systems, new applications, new market and new operating system.

Conceptually, labour productivity refers to any activity that contributes to the net-output of an entrepreneur, organisation or an individual, whether directly or indirectly (Baumol, 2010). According to Possamai and Andreassi (2017), labour productivity also known as workforce productivity, was defined as real economic output per labour hour. Growth in labour productivity is measured by the change in economic output per labour hour over a defined period. According to Rui and Joao (2015), it is the effectiveness of productive effort, especially in industry, as measured in terms of the rate of output per unit of input. Ngwiri, Mukulu, and Jane (2016) defined labour productivity as the efficient use of resources, land, labour, capital, energy, information, and materials by an organisation in its processes.

According to Massem (2015), labour productivity can be defined as output/input. Umunadi (2010) defined labour productivity as the measure of the efficiency of an entrepreneur or an organisation in converting inputs into useful outputs. Furthermore, labour productivity features includes an act of improvement in production process, manufacturing technique, and marketing structure which has brought about productivity most especially in the automobile assembly line and process of mass production that has reduced labour cost in production of parts and assembling of the automobile in the developed world (Strobel, 2014). Innovation according to Aziz and Samad (2016) influences the firm's labour productivity with direct and indirect impact; as such suggested that 
innovators could attain higher labour productivity compared to non-innovators in the automobile manufacturing industry. Labour productivity measures output per labour hour and is largely driven by investment in capital, technological progress, and human capital development (Lindsay, 2012). Similarly, Maciulyte-Sniukiene and Gaile-Sarkane (2014) are of the view that business and government can increase labour productivity of their workers by directly investing in or creating incentives for increases in technology and human or physical capital. Consequently, it is widely said that technology transfer has brought about massive labour productivity in the automobile industry globally (Ajibola, 2016; David, Richard, \& Regis, 2015).

\subsection{Nexus between Technology Transfer and Labour Productivity}

Scholarly works (Tai, 2018; Thompson, 2019; Pfluger \& Tabuchi, 2019; Vlajcica, Caputob, \& Dabica, 2019) found a significant positive relationship between labour productivity through direct transfers of technology and related companies technology spillovers in Europe, USA and China. Further findings from Tai (2018) study showed labour productivity gains was associated with direct linkages between foreign companies and domestic firms. Lars, Enrico, and Lars, (2016) found a significant positive relationship between technology innovation and labour productivity in the telecommunication industry. Lee, Byun and Park (2019) findings was in tandem with the findings of Lars, Enrico, and Lars, (2016) which found a significant positive effect of foreign investment on labour productivity spillover in the manufacturing industry in Europe. The findings of Diaz-Chao, Sainz-Gonzalez, and Torrent-Sellens (2015) corroborated Pfluger and Tabuchi (2019) findings that positive relationship exist between ICT investment and Britain labour productivity. Similarly, Maciulyte-Sniukiene and Gaile-Sarkane (2014) study found that knowledge acquisition and product innovation flexibility in SMEs are interconnected and it played a significant role in the creation of product innovation flexibility in SMEs.

This means that the extent to which the SMEs went to obtain knowledge, has a great bearing on their level of product innovation, however the study focused on one step in the knowledge management process, giving room for additional research on other aspects of the knowledge management process. Maciulyte-Sniukiene and Gaile-Sarkane (2014) findings coincided with Diaz-Chao, Sainz-Gonzalez, and Torrent-Sellens (2015) study that found a significant relationship between labour productivity gains along the supply chain obtained through direct transfers of knowledge and technology between linked firms from productivity effects through indirect foreign direct investment spillovers. Furthermore, Okoli and Binuomote (2015) found a significant positive relationship between information and communication technology (ICT) skill, risk management skill, innovative skill training and overall workforce productivity; as such the findings corroborated Newman, Rand, Talbot and Tarp (2015) findings. Additionally, Malikane and Chitambara (2017) found a general positive effect of FDI on labour productivity growth via the adoption of foreign technologies. Newman et.al (2015) findings coincided with Maciulyte-Sniukiene and Gaile-Sarkane (2014) findings. Jose, Gonzalez, Andres, and Inaki (2016) found a significant positive relationship between innovations through foreign companies and labour productivity in Uruguay which conceded with the findings of Diaz-Chao, Sainz-Gonzalez, \& Torrent-Sellens (2015) that found a positive significant relationship between technology innovation and labour productivity. Furthermore, Oyewale, Adeyemo, and Ogunleye (2013) found that a significant positive relationship exists between technological innovation and labour productivity in Nigeria.

Possamai and Andreassi (2017) study corroborated the finding of Oyewale, Adeyemo, and Ogunleye (2013) that technology transfer and adoption significantly aid labour productivity. Lopez, Minguela, Rodriguez, and Sandulli (2006) findings was consistent with previous empirical findings (Malikane, et al., 2017) that a positive impact of technology adoption exists on labour productivity. The link between technology intensity use and labour productivity is complex and from empirical point of view, the labour productivity impact technology intensity of use (Pantea, Sabadash, \& Biagi 2017), due to their multidimensional and intangible nature in general. Conversely, Miesing and Tang (2019) faulted the findings that there were substantial positive impacts of technology innovation on labour productivity, and that technology innovation is more ambiguous, and does not significantly improve labour productivity.

From the perspective of diffusion of innovation theory, the theory holds that the way organisation adopt technology, develop it technology infrastructure and technology innovation ultimately determine its competitive advantage (Rogers, 1995). Further, it is viewed that successful organisation are only those that are able to acquired technology, have absorptive capabilities (Ariguzo, Agbawo, \& Egwakhe, 2018), diffused same technology, building technological capabilities, and broader science to achieve corporate performance (David, Richard, \& Ragis, 2015). Therefore, there is an agreement among these studies and their results that technology transfer has a significant effect on labour productivity, as the various studies reviewed supported the positive association that exists between technology transfer dimensions (technology innovation, technology infrastructure, technology adoption and skill acquisition) and labour productivity. Since the diffusion of innovation theory 
supported the majority of empirical findings that technology transfer dimensions enhance labour productivity, the theory underpinned this study.

\section{Methodology}

The study used a cross-sectional survey research design, since it has the aptitude to gather information on people's opinion, experiences and behavioral pattern from a particular population within a shorter period of time (Wilberforce, Elegwa, \& John, 2016). The automobile manufacturing sector was selected due to its innovative evolvement, constant technological change and it significant to Nigerian economic growth and development (MAN, 2018). The study investigated all the automobile manufacturing companies in Nigeria, which include Innoson Motors, Stallion Group Automobile and Peugeot Nigeria. Although, Stallion Group Automobile consists of three subsidiaries automobile companies in Nigeria (Kia, Hyundai \& Nissan). The managers and engineers were selected as the respondents due to their technical and operational knowledge regarding technology transfer. A structured questionnaire was adapted and its construct, content and criterion validity were established before its usage. The KMO test results were greater than $5 \%$ and Bartlett test of Sphericity results were less than 5\% showing that statements contained in the instrument actually measured what was intended. In addition, the instrument's merit of internal consistency was established and the Cronbach's alpha values were above 0.7 which means that the instrument was reliable (Owino, Kibera, Munyoki, \& Wainaina, 2014).

\subsection{Model Specification}

In order to determine the effect of Technology Transfer $(X)$ on labour productivity $(Y)$, an econometric model was developed.

$$
Y=\mathrm{f}(X)^{\mathrm{n}}
$$

Hence the model was structured as such:

$$
\mathrm{LP}=\mathrm{a}_{0}+\beta_{1} \mathrm{KT}_{\mathrm{i}}+\beta_{1} \mathrm{SA}_{\mathrm{i}}+\beta_{1} \mathrm{TI}_{\mathrm{i}}+\beta_{2} \mathrm{TI}_{\mathrm{i}}+\beta_{3} \mathrm{TA}_{\mathrm{i}}+\mu_{\mathrm{i}}
$$

Where in:

LP $=$ Labour Productivity $(\mathrm{Y})$

KT $=$ Knowledge Transfer

$\mathrm{SA}=$ Skill Acquisition

$\mathrm{TI}=$ Technology Innovation

$\mathrm{TI}=$ Technology Infrastructure

$\mathrm{TA}=$ Technology Adoption

\section{Results and Discussions}

The objective of the study was to examine the effect of technology transfer dimensions on labour productivity of selected automobile manufacturing companies in Nigeria. Multiple regression analysis was used to test the hypothesis with labour productivity as the dependent variable, and technology transfer dimensions as the independent variable. The data for technology transfer dimensions were generated by adding all the responses of all items for knowledge transfer, technology innovation, skill acquisition, technology infrastructure and technology adoption, while that of labour productivity was generated by adding scores of responses of all items for the variable. Data from six hundred and seventy-five (675) respondents were analysed. The results of the multiple regression analysis are shown in Table 1 below. 
Table 1. Summary of multiple regression analysis for effects of technology transfer dimensions on labour productivity of selected Automobile manufacturing companies in Nigeria

\begin{tabular}{|c|c|c|c|c|c|c|c|c|}
\hline $\mathbf{N}$ & Model & $\beta$ & Sig. & $\mathbf{T}$ & $\begin{array}{l}\text { ANOVA } \\
\text { (Sig.) }\end{array}$ & $\mathbf{R}^{2}$ & $\begin{array}{l}\text { Adjusted } \\
\mathbf{R}^{2} \\
\end{array}$ & $\mathbf{F}(d f)$ \\
\hline \multirow{7}{*}{675} & (Constant) & 0.510 & 0.000 & 4.498 & \multirow{6}{*}{$0.000^{\mathrm{b}}$} & \multirow{6}{*}{0.386} & \multirow{6}{*}{0.381} & \multirow{6}{*}{$\begin{array}{l}84.043 \\
(5,669)\end{array}$} \\
\hline & Knowledge Transfer & -0.016 & 0.534 & -0.623 & & & & \\
\hline & Technology Innovation & 0.155 & 0.000 & 4.152 & & & & \\
\hline & Skill Acquisition & 0.155 & 0.000 & 3.848 & & & & \\
\hline & $\begin{array}{l}\text { Technology } \\
\text { Infrastructure }\end{array}$ & 0.123 & 0.001 & 3.295 & & & & \\
\hline & Technology Adoption & 0.344 & 0.000 & 10.143 & & & & \\
\hline & \multicolumn{7}{|c|}{$\begin{array}{l}\text { Predictors: (Constant), Technology } \\
\text { Innovation } \\
\text { Dependent Variable: Labour Product }\end{array}$} & , Technolo \\
\hline
\end{tabular}

Source: Field Survey, 2019

\subsection{Interpretation}

The coefficient of multiple determination, adjusted $R^{2}$ is $0.381\left(F_{(5,669)}=109.985, p=0.000\right)$ indicates a significant positive effect of technology transfer dimensions on labour productivity of selected automobile companies in Nigeria while the remaining $61.9 \%$ could be attributed to other factors not included in this model. Also, the F-statistics $(d f=5,669)=84.043$ at $p=0.000(p<0.05)$ indicates that the overall model is significant in predicting the effect of technology transfer dimensions on labour productivity. This means that technology transfer dimensions have a positive significant effect on labour productivity of selected automobile manufacturing companies in Nigeria.

Table 1 shows the multiple regression analysis results for the effect of technology transfer dimensions (knowledge transfer, technology innovation, skill acquisition, technology infrastructure and technology adoption) on labour productivity of selected automobile manufacturing companies in Nigeria. The results revealed that out of all the dimensions of technology transfer, technology innovation, skill acquisition, technology infrastructure and technology adoption have significant effect on labour productivity of selected automobile manufacturing companies in Nigeria. The results showed that technology innovation $(\beta=0.155, \mathrm{t}=4.152, p<0.05)$, skill acquisition $(\beta=0.155, \mathrm{t}=3.848, p<0.05)$, technology infrastructure $(\beta=0.123, \mathrm{t}=3.295, p<0.05)$ and technology adoption $(\beta=0.344, t=10.143, p<0.05)$ exhibited positive and significant effect on labour productivity while knowledge transfer $(\beta=-0.016, t=-0.623, p>0.05)$ have a negative and insignificant effect on labour productivity of selected automobile manufacturing companies in Nigeria. Of all the dimensions, technology adoption seems to have the greatest relative effect which shows that the firm needs to pay a closer attention to the kind of technology adopted. Furthermore, the result implies that technology innovation, skill acquisition, technology infrastructure and technology adoption are important determinants of labour productivity of selected automobile manufacturing companies in Nigeria.

The multiple regression model is thus expressed as:

$$
\mathrm{LP}=0.510+0.155 \mathrm{TI}+0.155 \mathrm{SA}+0.123 \mathrm{TI}+0.344 \mathrm{TA} \ldots \ldots . . \mathrm{eq} . \mathrm{i}
$$

Where:

LP $=$ Labour Productivity

$\mathrm{TI}=$ Technology Innovation

$\mathrm{SA}=$ Skills Acquisition

$\mathrm{TI}=$ Technology Infrastructure

$\mathrm{TA}=$ Technology Adoption

The results of the multiple regression analysis indicate that when technology innovation, skills acquisition, technology infrastructure and technology adoption are improved by one unit, labour productivity would be positively affected by an increase of $0.155,0.155,0.123$ and 0.344 respectively. This implies that an increase in technology innovation, skills acquisition, technology infrastructure and technology adoption would lead to an 
increase in labour productivity of selected automobile manufacturing companies in Nigeria. The result shows an overall statistical significance with $p=0.000(p<0.05)$ which implies that technology transfer dimensions are important determinants of labour productivity. The result suggests that automobile manufacturing companies should pay more attention to technology innovation, skills acquisition, technology infrastructure and technology adoption to improve their labour productivity.

\section{Discussions of Findings}

The results of the multiple regression analysis of technology transfer dimensions and labour productivity revealed that the components of technology transfer have significant positive effect on labour productivity of selected automobile manufacturing companies in Nigeria as shown in Adjusted $R^{2}$ of $0.381, F_{(5,669)}=109.985$, and $p=0.000$. Further, the individual coefficient results, technology adoption $(\beta=0.344, \mathrm{t}=10.143, p<0.05)$ had the greatest relative effect on labour productivity in automobile manufacturing companies in Nigeria. Thus, there is the need to pay a closer attention to technology adoption.

The statistical observation from this study findings is in line with previous studies that established significant positive effect of technology transfer on labour productivity (Diaz-Chao, Sainz-Gonzalez, \& Torrent-Sellens, 2015; Newman, Rand, Talbot, \& Tarp, 2015; Maciulyte-Sniukiene, \& Gaile-Sarkane, 2014). Similarly, Okoli and Binuomote (2015) sustained that technology infrastructure, and innovative skill trainings have significant positive effect on overall workforce productivity; as such the findings are also in consonance with Newman, Rand, Talbot and Tarp (2015). Possamai and Andreassi (2017) position that technology transfer and adoption significantly aid labour productivity is corroborated with current results. This work further supports Oyewale, Adeyemo, and Ogunleye (2013) that a significant positive relationship exists between labour productivity and technological innovation in Nigeria. In tandem with previous findings and empirical discussions, the diffusion of innovation theory is sustained and credence affirmed that technology transfer significantly affects labour productivity. However, Miesing and Tang (2019) conversed that technology infrastructure have no substantial positive impacts on labour productivity, and that technology innovation is more ambiguous, and does not significantly improve labour productivity which creates a departure due to context and methodological differences.

Theoretically, diffusion of innovation theory is in tandem with the findings of Diaz-Chao, Sainz-Gonzalez, and Torrent-Sellens (2015), Lars, Enrico, and Lars (2016) Newman, Rand, Talbot, and Tarp (2015) that technology transfer dimensions such as skill acquisition, technology infrastructure, technology adoption, and technology innovation significantly affect labour productivity of selected automobile manufacturing companies in Nigeria. The theory is significantly associated with labour innovativeness which in turn is positively related to organisational productivity (Possamai \& Andreassi, 2017). Based on these findings, theoretical support, and alignment of findings with previous scholars in the field of technology transfer and labour productivity, it can therefore be stated that technology transfer significantly affects labour productivity of selected automobile manufacturing companies in Nigeria.

Hence, the work concludes that technology transfer (knowledge transfer, skill acquisition, technology infrastructure, technology innovation, and technology adoption) affects labour productivity. The findings therefore remain highly important in both conceptual, theoretical as well as empirical terms. This study recommended that companies should invest more in technology transfer in order to increase workers' productivity.

\section{References}

Adebayo, O., Olagunju, K. O., Ogundipe, A., Salman, K. K., \& Francis, P. (2017). Scaling up agricultural innovation for inclusive livelihood and productivity outcomes in sub-saharan Africa: The case of Nigeria. African Development Review, 29(2), 121-134. https://doi.org/10.1111/1467-8268.12267

Adeyeye, T. C. (2014). The impact of technological innovation on organizational performance. Industrial Engineering Letters, 1(5), 1-5.

Agwu, A. E., Dimelu, M. U., \& Madukwe, M. C. (2018). Innovation system approach to agricultural development: Policy implications for agricultural extension delivery in Nigeria. African Journal of Biotechnology, 7(11), 1604-1611. https://doi.org/10.5897/AJB08.289

Ajibola, A. (2016). Capital market development, entrepreneurship performance and economic growth in Nigeria. Scholedge International Journal of Management \& Development, 3(2), 67-111.

Akinwale, Y. O., Adepoju, A. O., \& Olomu, M. O. (2017). The impact of technology innovation on SME's profitability in Nigeria. Int. J. Research, Innovation and Commercialization, 1(1), 74-92. 
https://doi.org/10.1504/IJRIC.2017.082299

Anderson, G. (2016). The economic impact of technology infrastructure for advanced robotics. (NIST, Gaithersburg, MD) NIST Economic Analysis Briefs 2. https://doi.org/10.6028/NIST.EAB.2

Andreea-Clara, M. (2015). Knowledge spillovers of FDI. Procedia Economics and Finance, 32, 1093-1099. https://doi.org/10.1016/S2212-5671(15)01573-7

Anyadike, N., Emeh, I., \& Ukah, F. (2012). Entrepreneurship development and employment generation in Nigeria: Problems and prospects. Universal Journal of Education and General Studies, 1(4), 088-102.

Argote, L., \& Ingram, P. (2012). Knowledge transfer: A basis for competitive advantage in firms. Organizational Behavior and Human Decision Processes, 82(1), 150-169. https://doi.org/10.1006/obhd.2000.2893

Ariguzu, V.A., Agbawo, J., \& Egwakhe, A. J. (2018). The relationship between innovation adoption predictors and market share of selected SMEs in Ota, Ogun State, Nigeria. UMYUK Journal of Economics and Development (UJED), 13(23), 312-322.

Aromolaran, A. K., Akerele, D., Oyekunle, O, Sotola, E. A., \& Taiwo, L. K. (2017). Attitudes of farmers to extension trainings in Nigeria: Implications for adoption of improved agricultural technologies in Ogun State Southwest Region. Journal of Agricultural Sciences, 62(4), 423-443. https://doi.org/10.2298/JAS1704423K

Arvanitis, S., \& Loukis, E. N. (2009). Information and communication technologies, human capital, workplace organization and labour productivity: A comparative study based on firm level data for Greece and $\begin{array}{lllll}\text { Switzerland. Information } & \text { Economics and }\end{array}$ https://doi.org/10.1016/j.infoecopol.2008.09.002

Awotide, B. A., Diagne, A., \& Omonona, B. T. (2012). Impact of improved agricultural technology adoption on sustainable rice productivity and rural farmers' welfare in Nigeria: A local average treatment effect (LATE) technique. Paper presented at the African Economic Conference.

Aziz, N. N. A., \& Samad, S. (2016). Innovation and competitive advantage: Moderating effects of firm age in foods manufacturing SMEs in Malaysia. Procedia Economics and Finance, 35, 256-266. https://doi.org/10.1016/S2212-5671(16)00032-0

Babalola, Y. T. (2013). Nigeria's information infrastructure policy: Implications for e-government. Arabian Journal of Business and Management Review, 2(11), 1-8. https://doi.org/10.12816/0002336

Barnes, J., Black, A. \& Tekachanont, K. (2017). Industrial policy, multinational strategy and domestic capability: A comparative analysis of the development of South Africa's and Thailand's Automotive Industries. European Journal of Development Research, 29(1), 37-53. https://doi.org/10.1057/ejdr.2015.63

Baumol, W. J. (2010). An entrepreneurial economist on the economics of entrepreneurship. Small Business Economics, 23(1), 1-7. https://doi.org/10.1023/B:SBEJ.0000026049.86377.df

Berraies, S., \& Chaher, M. (2014). Knowledge creation process and firms' innovation performance: Mediating effect of organizational learning. International Journal Resource Studies, 4(1), 204-222. https://doi.org/10.5296/ijhrs.v4i1.5517

Black, A., \& McLennan, T. (2016). The last frontier: Prospects and policies for the automotive industry in Africa. International Journal of Automotive Technology and Management, 16(2), 193-220. https://doi.org/10.1504/IJATM.2016.079232

Carlos, C. (2013). Innovation and technology transfer of environmentally sound technologies: The need to engage in a substantive debate. Review of European Community \& International Environmental Law, 29(1), 45-69.

Choi, Y. S., \& Lim, U. (2017). Contextual factors affecting the innovation performance of manufacturing SMEs in Korea: A structural equation modelling approach. Sustainability Journal, 9(6), 1-15. https://doi.org/10.3390/su9071193

Colovic, A., \& Lamotte, O. (2016). Technological environment and technology entrepreneurship: A cross-country analysis. Creativity \& Innovation Management, 24(4), 1-10. https://doi.org/10.1111/caim.12133

David, D., Richard, S., \& Regis, G. (2015). Collaboration, transferable and non-transferable knowledge and innovation: A study of a cool climate wine industry (Canada). Growth and Change, 46(1), 16-37. https://doi.org/10.1111/grow.12090 
Diaz-Chao, A., Sainz-Gonzalez, J., \& Torrent-Sellens, J. (2015). ICT, innovation, and firm productivity: New evidence from small local firms. Journal of Business Research, 68, 1439-1444. https://doi.org/10.1016/j.jbusres.2015.01.030

Gallaher, M. P., Oliver, Z. T., Reith, K. T., \& O’Connor, A. C. (2016). Economic analysis of technology infrastructure needs for advanced manufacturing: Journal of Smart Manufacturing, 1(6) 1-7. https://doi.org/10.6028/NIST.GCR.16-007

Jacqueline, M. H., \& Joshua, W. (2016). New skills, new jobs: Return migration, skill transfer, and business formation in Mexico. Social Problems, 63(3), 513-533. https:/doi.org/10.1093/socpro/spw021

Jose, L., Gonzalez, P., Andres, J., \& Inaki, P. (2016). Innovation-driven entrepreneurship in developing economies. Entrepreneurship \& Regional Development, 27(10), 555-573. https://doi.org/10.1080/08985626.2015.1075602

Lars, J., Enrico, B., \& Lars-Eric, L. (2016). A broadened innovation support for mutual benefits: Academic engagement by universities as part of technology transfer. International Journal of Technology Management \& Sustainable Development, 14(2), 71-91. https://doi.org/10.1386/tmsd.14.2.71_1

Lee, J. H., Byun, H. S., \& Park, K. S. (2019). How does product market competition affect corporate takeover in an emerging economy? International Review of Economics \& Finance, 60, 26-45. https://doi.org/10.1016/j.iref.2018.12.012

Lindsay, W. (2012). Developing technological capabilities in agro-industry: Ghana's experience with fresh pineapple exports.

Lopez, S., J. I., Minguela, B., Rodríguez, A., \& Sandulli, F. (2006). Is the internet productive. A firm-level analysis. Technovation, 26(7), 821-826. https://doi.org/10.1016/j.technovation.2005.03.002

Maciulyte-Sniukiene, A., \& Gaile-Sarkane, E. (2014). Impact of information and telecommunication technologies development on labour productivity. Procedia-Social and Behavioral Sciences, 110, 1271-1282. https://doi.org/10.1016/j.sbspro.2013.12.974

Malikane, C., \& Chitambara, P. (2017). Foreign direct investment, productivity and technology gap in African economies. Journal of African Trade, 4, 61-74. https://doi.org/10.1016/j.joat.2017.11.001

Manufacturers Association of Nigeria (2018). Sectoral report for 2018. Yearly handbook.

Marx, T. G. (2017). Impacts of industry attractiveness and competitive position on leadership. Management and Organizational Studies, 4(3), 1-13. https://doi.org/10.5430/mos.v4n3p1

Massem, A. (2015). An agri-business industry in the making. African Business Journal, 1(2), 1-6.

Mathu, K., \& Tlare, M. T. (2017). The impact of IT adoption in SMEs supply chains: A case of Gauteng and free state provinces of South Africa. South African Journal of Business Management, 48(3), 63-71. https://doi.org/10.4102/sajbm.v48i3.36

Miesing, P., \& Tang, M. (2018). Technology transfer institutions in China: A comparison of value chain and organizational structure perspectives. https://doi.org/10.1142/9789813149045_0003

Murad, M. A., \& Thomson, J. D. (2011). The importance of technology diffusion in Malaysian manufacturing SMEs. 3rd International Conference on Information and Financial Engineering.

National Bureau of Statistics. (2018). National Bureau of Statistic report on gross domestic product. Hand book 2018 edition.

Newman, C., Rand, J., Talbot, T., \& Tarp, F. (2015). Technology transfer. foreign investment and productivity spillovers. European Economic Review, 76, 168-187. https://doi.org/10.1016/j.euroecorev.2015.02.005

Ngwiri, B. M., Mukulu, E. J., \& Jane, G. (2016). Influence of knowledge technology transfer on the growth of micro and small catering enterprises in Nairobi County, Kenya. International Journal of Science and Research Publication, 6(1), 631-645.

Nicodemus, T., \& Egwakhe, A. J. (2019). Technology transfer and competitive advantage: Manager perspective. European Journal of Business and Management, 11(28), 66-75.

Okoli, B. E., \& Binuomote M. O. (2015). Skills training needed by business education student for successful entrepreneurship: Implication for colleges of education in Nigeria. British Journal of Education, 3(4), 1-9.

Okonji, C. (2019). Why Nigeria's auto sector is at a standstill. The nation's newspaper of $12^{\text {th }}$ May, 2019. 
Owino, E., Kibera, F., Munyoki, J., \& Wainaina, G. (2014). Service quality in Kenyan universities: Dimensionality and contextual analysis. European Journal of Business and Management, 6(11), 180-194.

Oyewale, I. O., Adeyemo, S. A., \& Ogunleye, P. O. (2013). Technological innovation: An imperative tool for entrepreneurship development in Nigeria. Australian Journal of Business and Management Research, 3(8), 41-47.

Pantea, S., Sabadash, A., \& Biagi, F. (2017). Are ICT displacing workers in the short run? Evidence from seven European countries. Information Economics and Policy, 39, 36-44. https://doi.org/10.1016/j.infoecopol.2017.03.002

Pfluger, M., \& Tabuchi, T, (2019). Comparative advantage, agglomeration economies and trade costs, Journal of Urban Economics, 109(3), 1-13. https://doi.org/10.1016/j.jue.2018.11.003

Possamai, H., \& Andreassi, A. (2017). What impacts the performance of technology organization? An entrepreneurial perspective. Revista Ibero-Americana de Estratégia (RIAE), 16(2), 179-211. https://doi.org/10.5585/ijsm.v16i2.2443

Price Waterhouse Coopers (2017). Digital factories 2020: Shaping the future of manufacturing. Retrieved from https://www.pwc.de/de/digitaletransformation/digital-factories-2020-shaping-the-future-of-manufacturing.p df

Rogers, E. M. (1995). Diffusion of innovations (4th ed.). New York: The Free Press.

Rui, B., \& Joao, L. (2015). Entrepreneurship, human capital, and regional development: Labour networks, knowledge flows, and industrial growth. Journal of Regional Science, 3(4), 1-16.

Santhosh, S. P. (2014). Improving entrepreneur's management skills through entrepreneurship training. Journal of Commerce \& Management Thought, 5(3), 459-474. https://doi.org/10.5958/0976-478X.2014.00334.6

Scott, T. J., Beaulieu, T. J., Rothrock, G. D., \& O’Connor, A. C (2016). Economic analysis of technology infrastructure needs for advanced manufacturing: Additive manufacturing. (NIST, Gaithersburg, MD) NIST GCR 16-006. https://doi.org/10.6028/NIST.GCR.16-006

Strobel, T. (2014). Directed technological change, skill complementarities and sectoral productivity growth: evidence from industrialized countries during the new economy. Journal of Productivity Analysis, 42(3), 255-275. https://doi.org/10.1007/s11123-014-0405-z

Tai, T. H. (2018). Exploring factors influencing technology transfer capabilities: Constructing a model through grounded theory. Procedia-Social and Behavioral Science, 56, 662-672.

Tassey, G. (2015). The Economic nature of knowledge embodied in standards for technology-based Industries. New York: Routledge Press.

Thompson, R. J. (2019). What is strategic alliance? Business planning and strategy. Reviewed by Elisa Shoenberger.

Torrent-Sellens, J., \& Díaz-Chao, A. (2014). ICT uses, innovation and SMEs productivity: modelling direct and indirect effects in small local firms. Internet Interdisciplinary Institute Working Paper Series, 14-001. https://doi.org/10.7238/in3wps.v0i0.2135

Umunadi, E.K. (2010). Acquisition of skills and competences by technical education teachers and instrument for national growth in Nigeria. Journal of Qualitative Education, 6(1), 1-9.

Vlajcica, D., Caputob, M., A. G., \& Dabica, C. M. (2019). Expatriates managers' cultural intelligence as promoter of knowledge transfer in multinational companies. Journal of Business Research, 94, 367-377. https://doi.org/10.1016/j.jbusres.2018.01.033

Wilberforce, S., Elegwa, M., \& John, K. (2016). Academic entrepreneurial intentions and the creation of university spin-off firms: Critical review. International Journal of Management, Accounting and Economics, 3(9), 532-544.

\section{Copyrights}

Copyright for this article is retained by the author(s), with first publication rights granted to the journal.

This is an open-access article distributed under the terms and conditions of the Creative Commons Attribution license (http://creativecommons.org/licenses/by/4.0/). 